Bentham OPen The Open Civil Engineering Journal

RESEARCH ARTICLE

\title{
Performance of Two-way RC Slabs Retrofitted by Different Configurations of High Performance Fibre Reinforced Cementitous Composite Strips
}

\author{
Mahdi A. Abbaszadeh ${ }^{1, *}$, Mohammad K. Sharbatdar ${ }^{1}$ and Ali Kheyroddin ${ }^{2}$ \\ ${ }^{I}$ Faculty of Civil Engineering, Semnan University, Semnan, Iran \\ ${ }^{2}$ Faculty of Civil Engineering, Semnan University, Semnan, Iran and Visiting Scholar at the Department of Civil \\ Engineering and Applied Mechanics, University of Texas, Arlington, TX, USA
}

Received: March 08, 2017

Revised: June 05,2017

Accepted: July 12, 2017

\begin{abstract}
:
Introduction:

Considering the promising results gained from several studies using cementitious composites with strain hardening behaviour (High Performance Fibre Reinforced Cementitious Composites, HPFRCC) for repair and retrofitting concrete flexural members, in this paper the possibility of using HPFRCC for retrofitting two-way RC slabs is investigated.
\end{abstract}

\section{Methods:}

A total of five two-way slabs were made and tested to failure. Three slabs were retrofitted with a variety of different types of retrofit configurations and two other slabs, having low and conventional reinforcement ratios, were used as control slabs. A novel technique of bonding, designated NSM-HPFRCC, is proposed. Flexural responses of all slabs are evaluated and the bonding behaviour and associated failure modes are investigated.

\section{Results and Conclusion:}

It is shown that the proposed retrofit configurations, especially when accompanied by the NSM-HPFRCC technique, can greatly improve the flexural performance of retrofitted slabs; hence, they can be used successfully to retrieve the flexural reinforcement deficiency of weak slabs.

Keywords: Two-way slabs, Steel fibres, HPFRCC, Retrofit, Flexural performance, NSM technique, Composites.

\section{INTRODUCTION}

Retrofitting of existing concrete structures due to a variety of causes such as deterioration of materials in severe environment, revisions in loading and design codes of practice and damages induced by an earthquake has encountered great development during recent years. However, significantly fewer investigations have been conducted on the strengthening of reinforced concrete slabs, especially two-way slabs. For RC slabs the techniques used for strengthening include: external post-tensioning, section enlargement, ferrocement cover, span shortening techniques and adding supplementary supports, each of them having advantages and disadvantages depending on the circumstances in which are applied [1]. Besides the traditional strengthening techniques, the performance of externally bonded steel plates $[2,3]$, fibre reinforced polymer (FRP) laminates $[4,5]$, textile reinforced mortars (TRM) $[6,7]$ and polyurethanecement composite (PUC) [8] have been extensively investigated. Although these techniques have been widely used, the retrofitted structural elements encountered several problems such as undesirable shear failure, heavy steel plates to be

* Address correspondence to this author at the Faculty of Civil Engineering, Semnan University, Semnan, Iran; P,O Box: 3513119111; Tel: +1 604 561 0529; E-mails: Mahdi.Abbaszadeh@yahoo.com; Abbaszadeh@iaumalard.ac.ir 
mounted and, steel corrosion by applying externally bonded steel plates $[9,10]$. The mismatch in the tensile strength and stiffness of FRP sheets with that of concrete can lead to a decrease of the overall structural member ductility, causing a more brittle failure [11], which prevents the total utilization of the tensile properties of the polymer.

In recent decades, a considerable effort has been made to incorporate randomly distributed short fibres of relatively low volume fraction (less than 2\%) to improve the brittle behaviour of cement-based materials. A new generation of fibre-reinforced cement-based composites (FRCC) showing strain hardening (or pseudo strain hardening) response, along with a significant tensile strain capacity and multiple fine cracks under uni-axial loading, is HPFRCC (High Performance Fibre Reinforced Cementitious Composite) [12,13]. Through a micromechanically designed interaction between fibres, matrix and their interfacial bond, HPFRCC could maintain load carrying capacity after the first cracking. Load can be transferred by fibre bridging from this crack plane back into brittle matrix and cause the formation of another crack, which may initiate from a different matrix defect site. Repetition of this process creates the phenomenon of multiple cracking with an intrinsically controlled crack width limit on the order of $200 \times 10^{-3}$ during tensile loading [14].

During these years, many investigations on the use of HPFRCC material have focused on the effects of bonding conditions between the substrate concrete and the HPFRCC [15], the layer thickness [16], fibre volume fraction and properties of the HPFRCC mix [17], the crack growth and propagation [18], optimization and flexural performance [19, 20] and tensile strain-hardening behaviour [21]. Recently, the feasibility of using HPFRCC for the rehabilitation and strengthening of deficient or damaged RC members has investigated widely [16, 22 - 29]. Unlike the steel and FRP techniques, not only the tensile strength, stiffness and coefficient of linear thermal expansion of HPFRCC's are comparable to that of concrete [15], but the durability of RC structures can be enhanced by controlling the width of cracks [16].

In this paper, the feasibility of using HPFRCC materials as a retrofit technique on two-way RC slabs is investigated. Different application techniques and configurations of HPFRCC are proposed. Then the load-deflection response curves of tested slabs and some flexural performance parameters derived from them, such as toughness (the energy absorption capacity), over-strength and ductility factors, initial stiffness and maximum strength are evaluated.

\section{RESEARCH SIGNIFICANCE}

Since, to the best of authors' knowledge, the effect of retrofitting two-way RC slabs using HPFRCC strips has not been studied yet in the technical literature, the scope of this study is to investigate the influence of HPFRCC materials in improving the flexural performance of two-way RC slabs by applying both techniques of casting wet mixes in place and attaching precast strips to the tension face of slabs. Also, based on the Near-Surface Mounted (NSM) method, a novel technique of retrofitting using HPFRCC, designated NSM-HPFRCC is proposed, by placing thin strips of HPFRCC into the grooves on the tension face of slabs aiming to enhance the bonding behaviour.

\section{EXPERIMENTAL PROGRAM}

\subsection{Materials}

Five two-way RC slabs with same geometrical dimensions of 1,500 $\mathrm{mm}$ long, 1,500 $\mathrm{mm}$ wide and $120 \mathrm{~mm}$ deep were constructed. All the slabs were made from a conventional concrete mix having average 28-days cylindrical compressive strength of $34.5 \mathrm{MPa}$. The edges of the slabs represent the contra-flexure lines of an actual two-way slab system. Two-way slabs with low or medium reinforcement ratios tend to fail in flexure rather than in punching shear. For two way slabs that have reinforcement ratios of $1.0 \%$ and more, the mode of failure tends to be the punching shear type of failure [30]. Thus, In order to ensure a flexural failure mode in the slabs and highlight the effects of retrofit technique, four of the slabs were designed by a low reinforcement ratio near the minimum steel reinforcement ratio (0.2\%) according to ACI 318-99 [31] simulating lightly reinforced or, alternatively, moderately corroded slabs. In these specimens, ten $12 \mathrm{~mm}$ steel bars at spacing of $300 \mathrm{~mm}$ with an average effective depth of $80 \mathrm{~mm}$ provided the flexural reinforcement in two perpendicular directions in one layer near the tension face.

One out of these four specimens remained un-retrofitted to be tested to failure as weak slab and designated Control Slab No.1. The fifth slab specimen having a flexural steel reinforcement ratio twice the other slabs also remained unretrofitted to reveal the performance of a conventional slab. Its only difference was in the placement of $12 \mathrm{~mm}$ steel bars, which was $135 \mathrm{~mm}$, totalling 22 in number, and designated Control Slab No.2. The anchorage of bars was 
provided by 180 degree hooks at both ends. The general layout of a test specimen and steel reinforcement details are shown in Fig. (1).

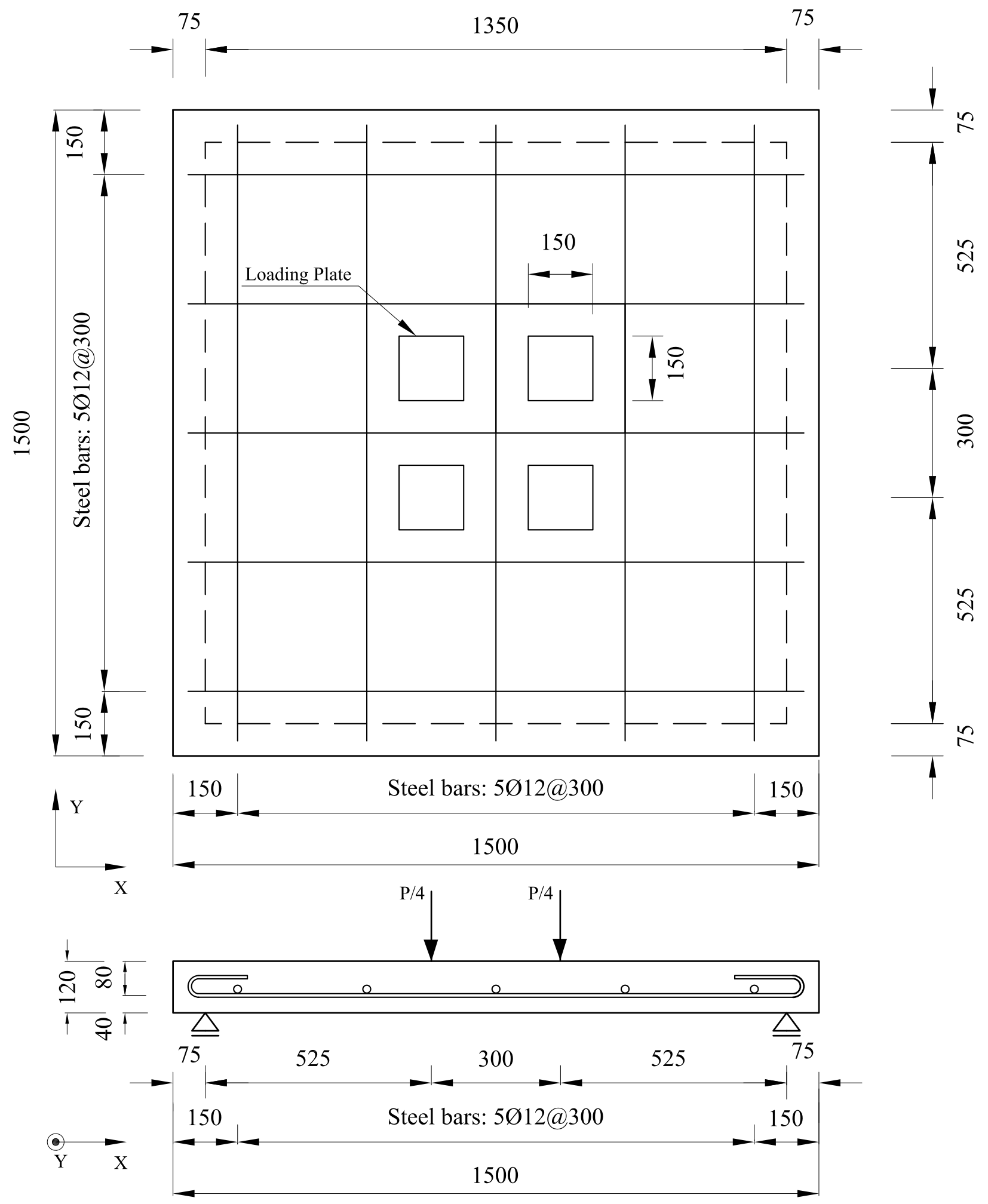

Fig. (1). General layout of a test specimen and steel reinforcement details. 
According to Naghibdehi and Sharbatdar [17] an HPFRCC mix which exhibits a very ductile with a relatively high tensile strength in its hardened state was chosen for experimental tests in this paper. A volume fraction of $2 \%$ hookended steel fibres with the ratio of length to diameter (L/D) equal to 47.62 (50 mm long and $1.05 \mathrm{~mm}$ diameter) was used, (Fig. 2a). In order to prevent bulking, the steel fibres were gradually added during the mixing process. The distribution of fibers in the HPFRCC mix is presented in Fig. (2b). Also, portland cement (type 42.5R) and Notral N102 super-plasticizer were used in the HPFRCC mix proportion. Tables (1 and 2) present the mix proportions and the mechanical properties of materials used in the specimens.

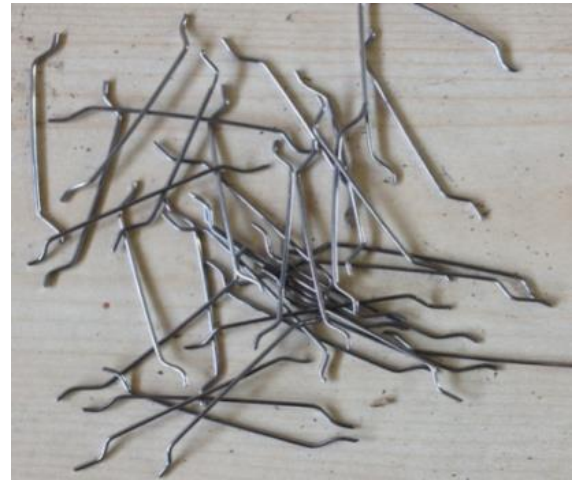

(a)

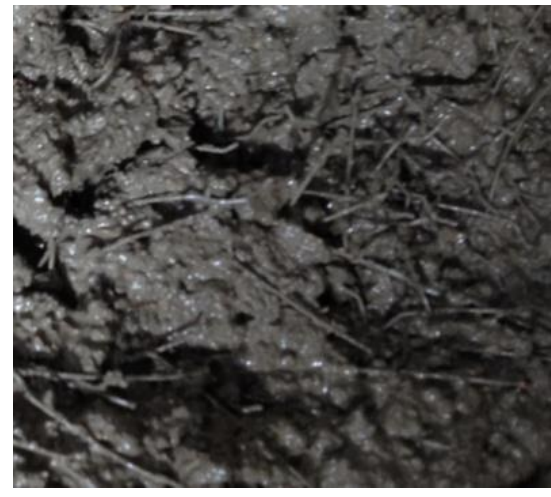

(b)

Fig. (2). (a) Hook-ended steel fibres and (b) distribution of fibres in HPFRCC mix.

Table 1. Mix proportions of HPFRCC and concrete per $1 \mathrm{~m}^{3}$.

\begin{tabular}{|c|c|c|c|c|c|c|c|}
\hline \multirow{2}{*}{ Material } & \multirow{2}{*}{$\begin{array}{c}\text { Cement } \\
(\mathrm{Kg})\end{array}$} & \multicolumn{2}{|c|}{ Fine Aggregate (Kg) } & \multirow{2}{*}{ Coarse Aggregate (Kg) } & \multirow{2}{*}{ Water $(\mathbf{K g})$} & \multirow{2}{*}{ Super Plasticizer (Kg) } & \multirow{2}{*}{$\begin{array}{l}\text { Steel Fibers, } \\
\text { v.f. } 2 \%(\mathrm{Kg})\end{array}$} \\
\hline & & $\mathrm{D}<2.36(\mathrm{~mm})$ & $2.36<\mathrm{D}<4.75(\mathrm{~mm})$ & & & & \\
\hline HPFRCC & 812 & 609 & 362 & - & 325 & 4.06 & 158 \\
\hline Concrete & 429 & & 662 & 1222 & 186 & - & - \\
\hline
\end{tabular}

Table 2. Mechanical properties of materials used in the specimens.

\begin{tabular}{|c|c|c|c|c|c|c|}
\hline Material & $\begin{array}{c}\text { Elastic Modulus } \\
(\mathbf{G P a})\end{array}$ & $\begin{array}{c}\text { Compressive } \\
\text { Strength (MPa) }\end{array}$ & $\begin{array}{c}\text { Yield Stress } \\
(\mathbf{M P a})\end{array}$ & Yield Strain & $\begin{array}{c}\text { Ultimate Tensile } \\
\text { Stress (MPa) }\end{array}$ & $\begin{array}{c}\text { Ultimate Tensile } \\
\text { Strain }\end{array}$ \\
\hline Concrete $^{1}$ & 29.368 & 34.5 & - & - & - & - \\
\hline HPFRCC $^{1}$ & 28.988 & 65.2 & - & - & - & - \\
\hline Steel bar $^{1}$ & 200 & - & 338 & 0.00169 & 523.8 & 0.155 \\
\hline Steel fibre $^{2}$ & 200 & - & - & - & 1300 & - \\
\hline Epoxy Resin (Sikadur 30) $^{2}$ & 4.5 & - & - & - & 25 & 0.01 \\
\hline
\end{tabular}

1. Average values obtained from material testing.

2. Values reported by the manufacturer.

\subsection{NSM-HPFRCC Strips}

In order to resolve the problem of debonding and, in some cases, eliminating the need for repairing spalled or delaminated concrete cover before strengthening, and as a result preventing exertion of excessive loads due to strengthening, a novel technique of Near-Surface Mounted (NSM) using HPFRCC was developed. The term "nearsurface" is used to distinguish this technique from the case where Externally Bonded Reinforcement (EBR) is utilized. This concept is not completely new, since it was first used in Europe for the strengthening of reinforced concrete structures in the 1940s. This pioneering technique consisted of placing reinforcing bars in grooves located in the concrete cover, after which the grooves were filled with cement mortar [32]. Several experimental tests have indicated the benefits of NSM technique such as: high levels of strengthening efficacy and, when compared with EBR, a significant decrease of the probability of debonding, mechanical actions, effects of aging, increase in the load carrying capacity of RC members, easy to apply and cost effective $[33,34]$. While the NSM technique using laminate strips of fibre reinforced polymer has been extensively used as a strengthening strategy for increasing the load-carrying capacity 
of slabs [35 - 37], in the present research, HPFRCC strips take the place of FRP laminate strips. The new developed technique is designated NSM-HPFRCC.

\subsection{Test Specimens}

As mentioned earlier, aiming to evaluate the flexural performance parameters of the retrofitted slabs with HPFRCC strips, three different types of retrofit configurations were developed. The first two types consisted of in-situ cast HPFRCC strips, i.e. wet application technique, in the way that $8 \mathrm{HPFRCC}$ strips were formed in the pre-devised grooves inside the tension face of the slab in type D and 8 HPFRCC strips were cast over the tension face in type E, both in two perpendicular directions. The third type was comprised of 4 in-situ cast HPFRCC strips formed in the predevised grooves inside the tension face of the slab in one direction and 4 precast HPFRCC strips attached over the tension face of the slab using an epoxy resin (sikadur 30) in the perpendicular direction, type F. The 4 precast strips, $1500 \mathrm{~mm}$ long, $150 \mathrm{~mm}$ wide and $30 \mathrm{~mm}$ deep, were made as flat strips in different moulds and cured for 28 days before being attached. In total, 8 HPFRCC strips, 4 in each direction placed at $300 \mathrm{~mm}$ on the tension face, were applied for each two-way slab, (Fig. 3).

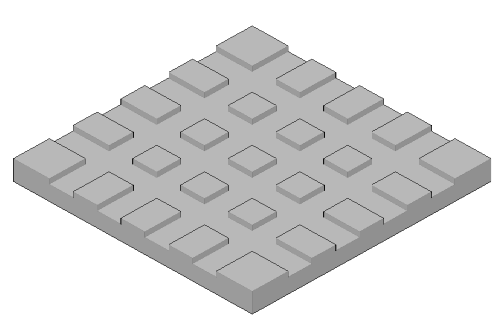

(a)

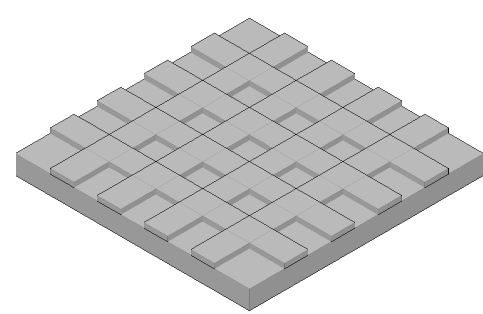

(b)

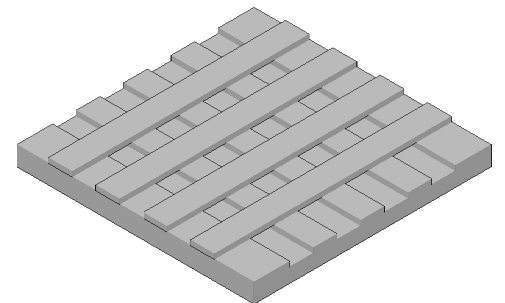

(c)

Fig. (3). Schematic layouts of retrofit configurations (tension face upward): (a) 8 two-way grooves to be filled with HPFRCC in slab type D, (b) 8 in-situ two-way HPFRCC strips cast over the tension face in slab type E and (c) 4 one-way grooves to be filled with HPFRCC and 4 precast HPFRCC strips attached over the tension face in the perpendicular direction in slab type F.

In order to apply HPFRCC over the tension face of the slabs at the age of 7 days, the slabs were cast in a 180 degree rotated position about their in-plane axis, in a manner that the tension face was upward and the reinforcements were placed close to this face. Because of the difficulty in cutting the grooves, they were pre-devised inside the tension face of slabs using 1500x150x30 mm moulds as hollow spaces before concrete casting. Casting HPFRCC in these grooves is a novel NSM technique, designated NSM-HPFRCC, the advantage of which in improving the bond behaviour and flexural performance parameters of retrofitted slabs will be discussed later in the present paper. The specimen fabrication and strengthening procedure of slab type D is illustrated in Fig. (4). The retrofitting operation took place in one stage using a similar HPFRCC mix for all the slabs. After applying HPFRCC, the retrofitted slabs were water cured for 28 days. Some information regarding strip types used for each retrofit configuration are summarized in Table $\mathbf{3}$.

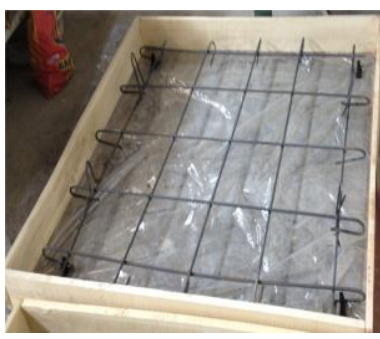

(a)

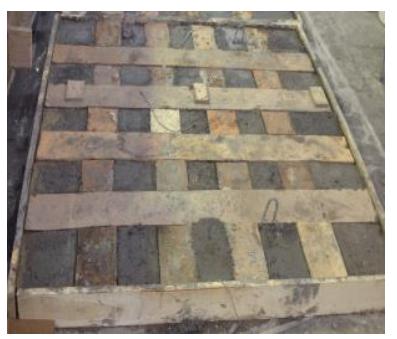

(b)

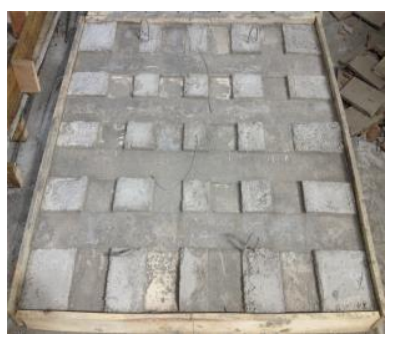

(c)

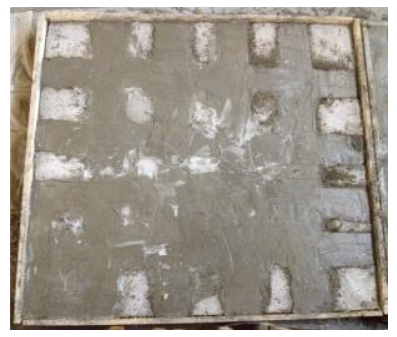

(d)

Fig. (4). Specimen fabrication and strengthening procedure of slab type D: (a) placing steel reinforcement into the slab's mould, (b) pre-devising grooves by placing strip moulds into the tension face of slab before concrete hardening, (c) grooves formed on the tension face after removing the moulds and (d) strengthening by applying HPFRCC to the grooves. 
Table 3. General information of strip types used for each retrofit configuration.

\begin{tabular}{|c|c|c|c|c|c|}
\hline Retrofit Configuration & Steel Bar Spacing (mm) & Level of Application & NSM Strip & Precast Strip & $\begin{array}{c}\text { EBR } \\
\text { Strip }\end{array}$ \\
\hline Control No.1 & 300 & - & - & - & - \\
\hline Control No.2 & 150 & - & - & - & - \\
\hline Type D & 300 & Inside Tension face & $2-$ Way & - & \\
\hline Type E & 300 & Over Tension face & - & - & $2-$ Way \\
\hline \multirow{2}{*}{ Type F } & \multirow{2}{*}{300} & Inside Tension face & $1-$ Way & & \multirow{2}{*}{ 1-Way } \\
\cline { 2 - 5 } & Over Tension face & & - \\
\hline
\end{tabular}

Here, it must be noted that although, as mentioned above, cutting these grooves may seem to be hard work in the hardened concrete surfaces, in some cases, it is needed to repair spalled or delaminated concrete surfaces before retrofitting, by removing the deteriorated concrete surfaces and filling the gaps with repair materials, (Fig. 5). Therefore, by using HPFRCC as filler, it not only plays the role of repair material, but also can improve the bond behaviour and flexural performance of the repaired member. In fact, the purpose of using them here was to evaluate the effect of filling spalled or delaminated concrete surfaces with HPFRCC materials, in improving the flexural behaviour of deficient slabs by simulating some NSM-HPFRCC strips.

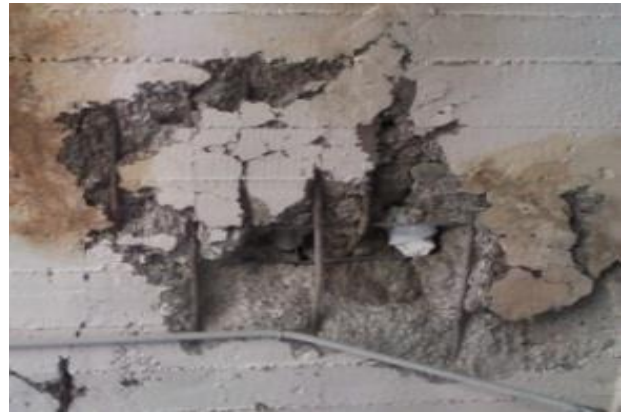

(a)

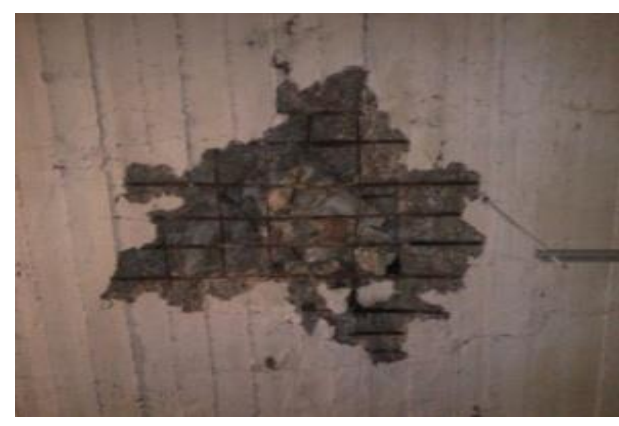

(b)

Fig. (5). Some examples of spalled or deteriorated concrete surfaces in slabs that must be repaired before strengthening.

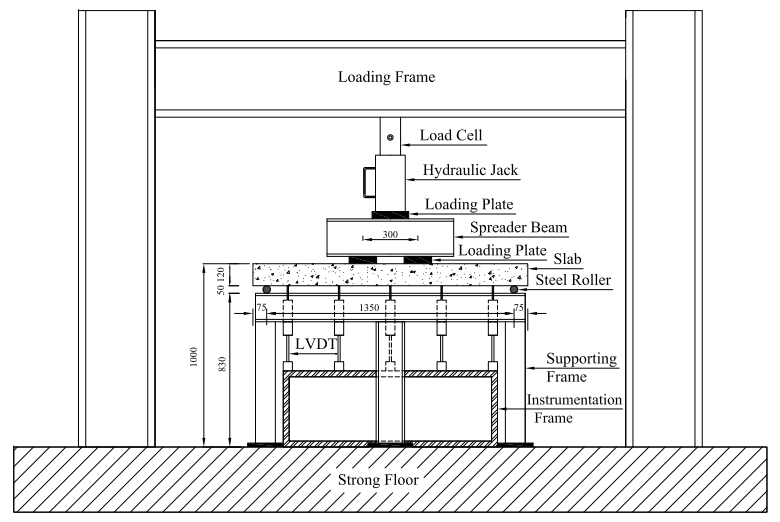

(a)

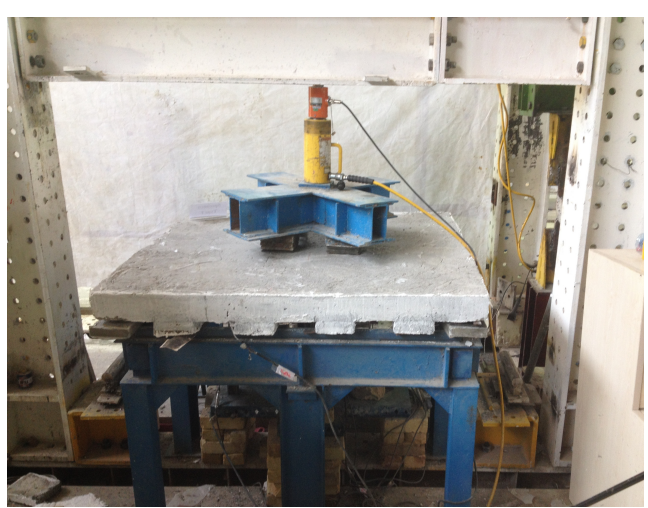

(b)

Fig. (6). (a) General layout of instrumentation and (b) test setup.

\section{TEST SETUP}

At first the retrofitted slabs were rotated 180 degrees (tension face downward) and then laid over four steel rollers, $1350 \mathrm{~mm}$ long, on the supporting frame along the edges. A $500 \mathrm{kN}$ hydraulic jack was used to test the slabs to failure under monotonic loading. The loads were transferred to the slab using a cruciform spreader steel beam through four loading points. The loading points and supports were selected to give an effective span of $1350 \mathrm{~mm}$ and a shear span of $300 \mathrm{~mm}$ in both directions, as shown in Fig. (6). 
The vertical deflection of the slabs was measured using 9 linear variable deflection transducers (LVDT) in two perpendicular directions. One LVDT was placed underneath the slab centre to record the central deflection of the specimen and the other 8 LVDTs at $300 \mathrm{~mm}$ and $570 \mathrm{~mm}$ from it in two perpendicular directions to attain deflection profiles. Five $10 \mathrm{~mm}$ strain gauges were bonded to two bars crossing at the centre line of the slab, one in the centre point and two others at $600 \mathrm{~mm}$ from it on each bar.

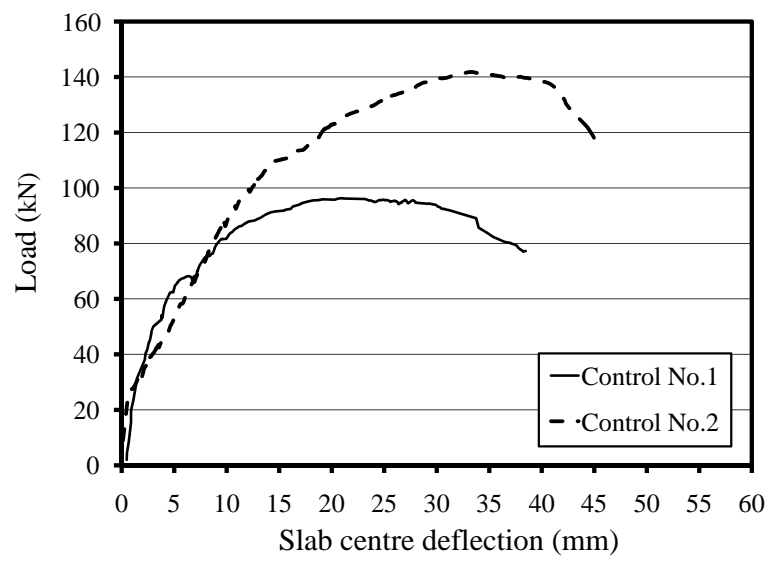

(a)

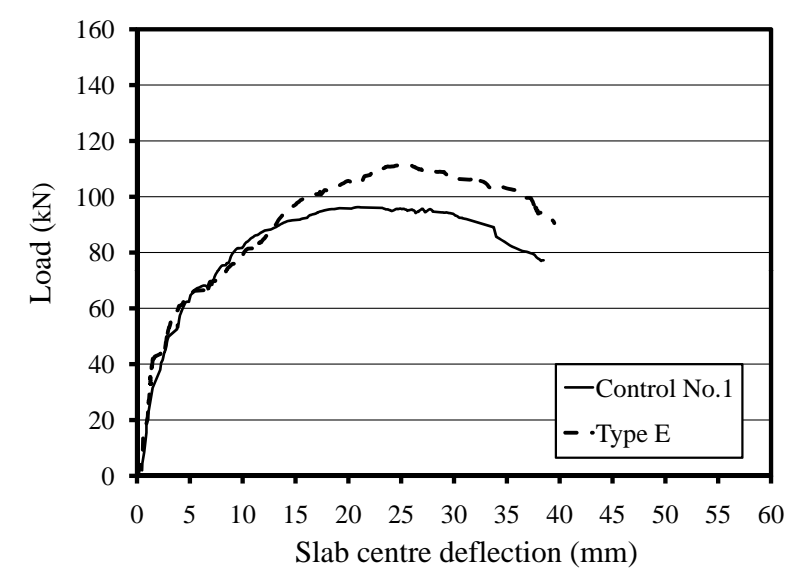

(c)

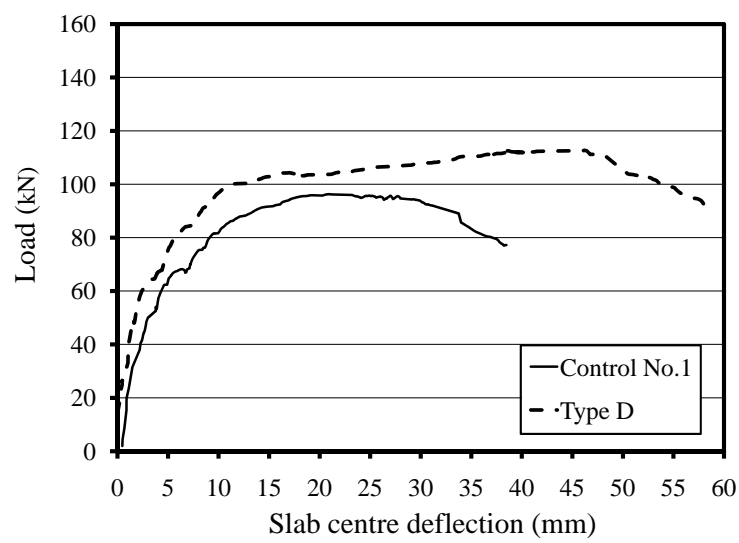

(b)

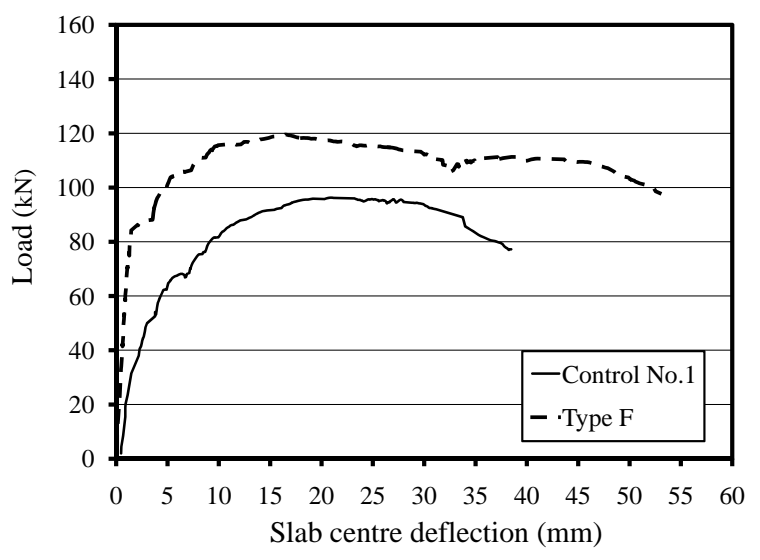

(d)

Fig. (7). Load-deflection response curves of control and retrofitted slabs: (a) control slabs No.1 and No.2, (b) control slabs No.1 and slab type D, (c) control slabs No.1 and slab type E and (d) control slab No.1 and slab type F.

\section{RESULTS AND DISCUSSION}

\subsection{Load-deflection Curve}

Load-deflection response curves of control slabs No.1 and No.2, simulating the behaviour of weak and conventional slabs respectively, and the three other slabs retrofitted with different HPFRCC strips, are shown in Fig. (7). The maximum deflection recorded at the centre of slab at any loading stage was used for plotting the load-deflection curve in this figure, and those referred to hereafter. In general, the load-deflection response curve can be divided into 3 stages: initial stiffness stage, pre-yield stage and post-yield strain hardening stage. Viewing the load-deflection response curves, it is obvious that control slabs behaved similarly in the first stage, but control slab No.2, with a higher ratio of reinforcement (two times) shows a higher value of yield strength followed by a considerable post-yield strain hardening behaviour, which is a common phenomenon of steel in RC members. Again, the response curves of slabs type D and E are identical to control slab No.1 until reinforcement yielding. The effect of their retrofit configurations is more highlighted in the post-yield strain hardening stage where they reached higher values of load-bearing capacity. While slab type E failed in the same ultimate deflection as that of slab No.1, slab type D behaved very ductile until failure and gained the highest ultimate deflection among slabs. On the contrary, slab type F behaved very stiff till yielding which is due to precast HPFRCC strips included in its retrofit configuration. 
Tables (4 and 5) summarize some of the test results derived from the load-deflection curves, including loading stages $\left(\mathrm{P}_{\mathrm{cr}}, \mathrm{P}_{\mathrm{y}}, \mathrm{P}_{\max }, \mathrm{P}_{\mathrm{u}}\right)$ and corresponding deflections $\left(\Delta_{\mathrm{cr}}, \Delta_{\mathrm{y}}, \Delta_{\max }, \Delta_{\mathrm{u}}\right)$. In these tables, cracking strength $\left(\mathrm{P}_{\mathrm{cr}}\right)$ which is used to calculate the initial stiffness $\left(\mathrm{K}_{\mathrm{i}}\right)$ of slab, is a strength at which the first cracks appears, and yield strength $\left(\mathrm{P}_{\mathrm{y}}\right)$ corresponds to the yielding strain of steel reinforcement bars recorded by the strain gauge mounted at the centre of slab. Also, the values of flexural performance parameters of control and retrofitted slabs are evaluated and listed in Table. $\mathbf{6}$.

Table 4. Load-deflection response parameters of slabs at cracking and steel bar's yielding strengths.

\begin{tabular}{|c|c|c|c|c|c|c|c|}
\hline \multirow{2}{*}{ Retrofit Configuration } & \multirow{2}{*}{\begin{tabular}{|} 
HPFRCC Strip \\
Type
\end{tabular}} & \multicolumn{2}{|c|}{ Cracking } & \multirow{2}{*}{ Initial Stiffness, $\mathrm{K}_{\mathrm{i}}(\mathrm{kN} / \mathrm{mm})$} & \multirow{2}{*}{ Increase in $K_{i}(\%)$} & \multicolumn{2}{|c|}{ Yielding } \\
\hline & & $P_{\mathrm{cr}}(\mathrm{kN})$ & $\Delta_{\mathrm{cr}}(\mathrm{mm})$ & & & $P_{y}(\mathbf{k N})$ & $\Delta_{\mathrm{y}}(\mathrm{mm})$ \\
\hline Control No.1 & - & 36 & 1.48 & 24.36 & - & 73 & 8.26 \\
\hline Control No. 2 & - & 33 & 1.50 & 21.86 & -10.3 & 107 & 13.78 \\
\hline Type D & 2-way NSM & 50 & 1.54 & 32.47 & $33.3(48.5)^{1}$ & 86 & 7.83 \\
\hline Type E & 2-way EBR & 43 & 1.52 & 28.29 & $16.1(29.4)^{1}$ & 71 & 7.01 \\
\hline Type F & $\begin{array}{l}\text { 1-way NSM + } \\
\text { 1-way Precast }\end{array}$ & 86 & 1.47 & 58.50 & $140.2(167.6)^{1}$ & 103 & 5.67 \\
\hline
\end{tabular}

1. Values in respect to control slab No.2 in parenthesis.

Table 5. Load-deflection response parameters of slabs at maximum and ultimate strengths.

\begin{tabular}{|c|c|c|c|c|c|c|c|c|}
\hline \multirow{2}{*}{ Retrofit Configuration } & \multirow{2}{*}{$\begin{array}{c}\text { HPFRCC Strip } \\
\text { Type }\end{array}$} & \multicolumn{2}{|c|}{ Maximum } & \multirow{2}{*}{$\begin{array}{c}\text { Increase in } \\
P_{\max }(\%)\end{array}$} & \multicolumn{2}{|c|}{ Ultimate } & \multirow{2}{*}{$\begin{array}{c}\text { Increase in } \\
\Delta_{\mathrm{u}}(\%)\end{array}$} & \multirow{2}{*}{ Failure Mode } \\
\hline & & $\mathbf{P}_{\max }(\mathrm{kN})$ & $\Delta_{\max }(\mathrm{mm})$ & & \begin{tabular}{|l|}
$\mathbf{P}_{\mathrm{u}}(\mathbf{k N})$ \\
\end{tabular} & $\Delta_{\mathrm{u}}(\mathrm{mm})$ & & \\
\hline Control No.1 & - & 97 & 25.01 & - & 77 & 38.48 & - & Pure Flexural \\
\hline Control No.2 & - & 143 & 33.02 & 47.42 & 115 & 45.48 & 18.21 & Flexural+ Punching Shear \\
\hline Type D & 2-way NSM & 114 & 46.14 & $17.52(-20.3)^{1}$ & 91 & 58.08 & $50.95(27.7)^{1}$ & Flexural+ Punching Shear \\
\hline Type E & 2-way EBR & 113 & 25.77 & $16.49(-21)^{1}$ & 90 & 39.49 & $2.64(-13.2)^{1}$ & Strip Debonding \\
\hline Type F & $\begin{array}{l}\text { 1-way NSM + } \\
\text { 1-way Precast }\end{array}$ & 121 & 16.53 & $25.27(-15.4)^{1}$ & 98 & 52.93 & $37.56(16.4)^{1}$ & Flexural + Punching Shear \\
\hline
\end{tabular}

1. Values in respect to control slab No.2 in parenthesis.

Table 6. Flexural performance parameters of retrofitted slabs.

\begin{tabular}{|c|c|c|c|c|c|c|c|}
\hline $\begin{array}{c}\text { Retrofit } \\
\text { Configuration }\end{array}$ & $\begin{array}{c}\text { HPFRCC } \\
\text { Strip } \\
\text { Type }\end{array}$ & $\begin{array}{c}\text { Toughness } \\
(\mathbf{k N . m m})\end{array}$ & $\begin{array}{c}\text { Increase in } \\
\text { Toughness (\%) }\end{array}$ & $\begin{array}{c}\text { Ductility, } \\
\boldsymbol{\mu}\left(\boldsymbol{\Delta}_{\mathbf{u}}\right)\end{array}$ & $\begin{array}{c}\text { Increase in } \\
\boldsymbol{\mu}\left(\boldsymbol{\Delta}_{\mathbf{u}}\right) \mathbf{( \% )}\end{array}$ & $\begin{array}{c}\text { Over-strength } \\
\left(\mathbf{P}_{\mathbf{m a x}} / \mathbf{P}_{\mathbf{y}}\right)\end{array}$ & $\begin{array}{c}\text { Increase in Over- } \\
\text { strength }(\mathbf{\%})\end{array}$ \\
\hline Control No.1 & - & 3160.76 & - & 4.66 & - & 1.33 & - \\
\hline Control No.2 & - & 5074.52 & 60.55 & 3.30 & -29.1 & 1.34 & 0.6 \\
\hline Type D & 2-way NSM & 5825.80 & $84.31(14.8)^{1}$ & 7.42 & $59.2(124.7)^{1}$ & 1.33 & $0(-0.8)^{1}$ \\
\hline Type E & 2-way EBR & 3595.32 & $13.76(-29.1)^{1}$ & 5.63 & $20.9(70.7)^{1}$ & 1.59 & $19.8(19.1)^{1}$ \\
\hline Type F & $\begin{array}{l}\text { 1-way NSM+ } \\
\text { 1-way Precast }\end{array}$ & 5748.36 & $81.87(13.3)^{1}$ & 9.34 & $100.4(182.8)^{1}$ & 1.17 & $-11.6(-12.1)^{1}$ \\
\hline
\end{tabular}

1. Values in respect to control slab No.2 in parenthesis.

\subsection{Failure Modes}

Control slab No.1 revealed a ductile failure mode. As the applied load increased, first the reinforcing bar located at the centre of slab yielded, and in consequence the yielding extended gradually towards the edges of slab, causing the formation of some yield lines which ended in slab failure in a pure flexural manner. In contrast, control slab No.2 and retrofitted slabs exhibited a combination of flexural and local shear failures caused by punching of loading plates through slab thickness. Failure took place after significant yielding in the flexural reinforcements where the regions near the loading plates entered into a plastic state followed by slab punching. Fig. (8) shows the crack patterns formed on the tension face of slabs at failure. While debonding of EBR strips over the tension face occurred in slab type E, both slabs type D and F which were retrofitted with NSM-HPFRCC strips and a combination of NSM-HPFRCC plus precast strips respectively, showed no signs of debonding. 


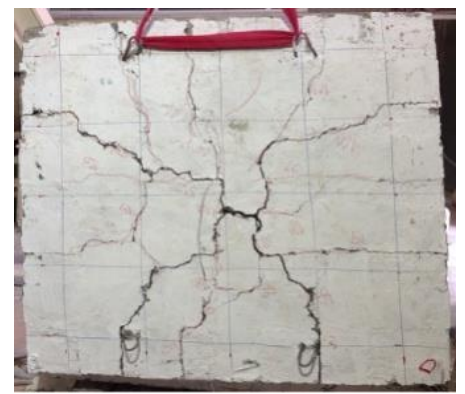

(a)

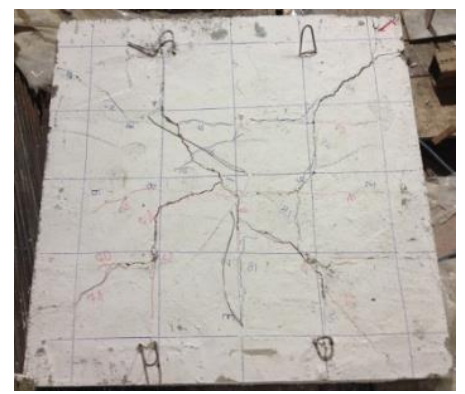

(d)

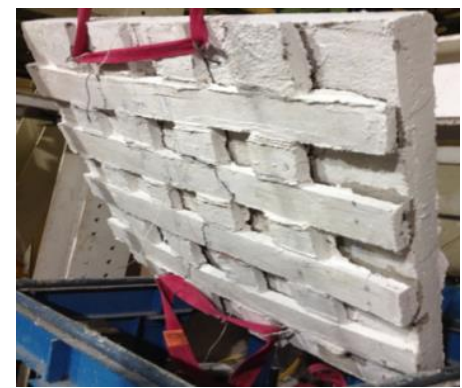

(b)

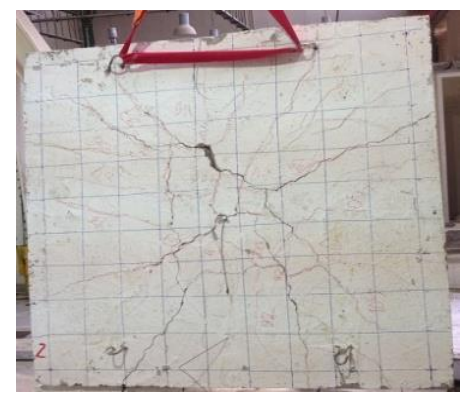

(e)

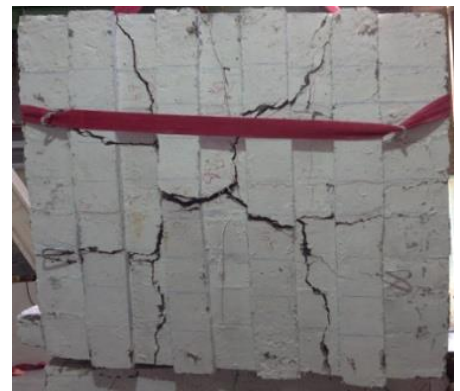

(c)

Fig. (8). Cracking patterns formed on the tension face of slabs at failure: (a) Slab type D, (b) Slab type E, (c) Slab type F, (d) Control slab No.1 and (e) Control slab No.2.

\subsection{Initial Stiffness}

As expected, the initial or pre-cracking stiffness $\left(\mathrm{K}_{\mathrm{i}}\right)$, which is calculated from the load-deflection curve as the tangent stiffness of the un-cracked stage, of all the retrofitted slabs shows higher value in comparison with that of control slabs. While the cracking deflections of retrofitted slabs (1.47 to $1.54 \mathrm{~mm}$ ) are about the same as for control slabs $(1.48$ and $1.50 \mathrm{~mm})$, the increase in the initial stiffness is a result of the increase in the cracking strength, and shows the effect of the HPFRCC strips. The first crack observed at the loads of 36 and $33 \mathrm{kN}$ in control slabs No.1 and No.2, respectively. As mentioned, retrofitted slabs reached higher values of the cracking load ranging from $43 \mathrm{kN}$ in slab type E to $86 \mathrm{kN}$ in slab type F. The higher increase in the cracking load in slab type F, which was retrofitted with both precast and NSM-HFRCC strips, is due to the attached precast strips. This shows the effectiveness of the current configuration in improving cracking behaviour and reducing crack width. The observed behaviour is apparent in Fig. (9a), where the values of initial stiffness are plotted.

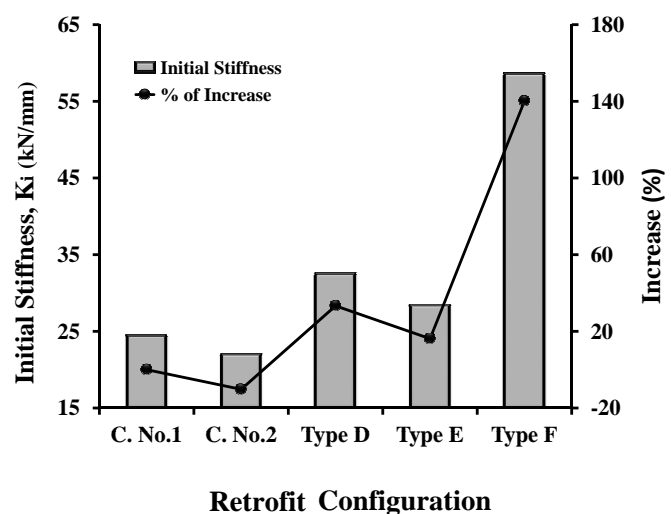

(D)

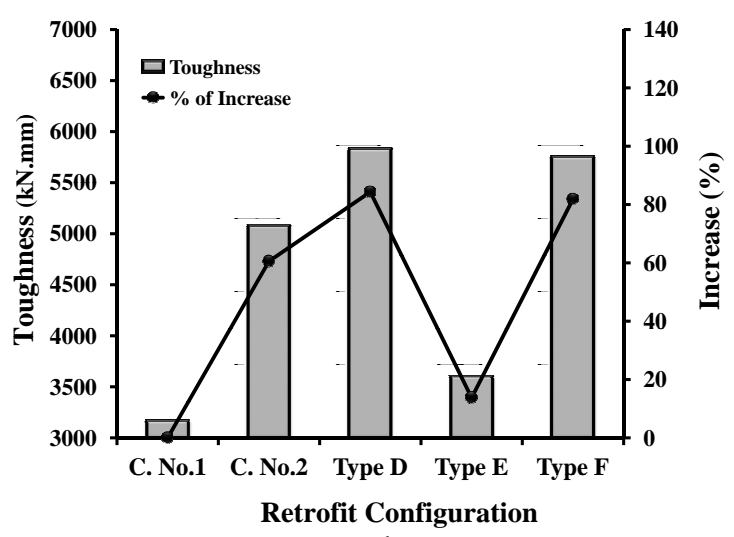

(b)

Fig. (9). Comparison of the values of (a) initial stiffness and (b) toughness of control and retrofitted slabs. 


\subsection{Toughness}

Toughness, which reveals the energy absorption capacity of slabs, is evaluated by the area under load-deflection curve. For comparing the effect of different types of HPFRCC strips in increasing the toughness of weak slabs, the values of toughness are calculated and plotted in Fig. (9b). As can be seen, the lowest amount of toughness belongs to control slab No.1, weak slab, which is about $60 \%$ less than that of control slab No.2, conventional slab. Slabs retrofitted with configurations type $\mathrm{D}$ and $\mathrm{F}$ show increases of $84 \%$ and $82 \%$ in toughness, respectively, which are both higher values than that of conventional slab (60.5\% increase). The poorer performance (14\% increase) is for the slab retrofitted with configuration type $\mathrm{E}$ which can be explained as a result of strip debonding.

\subsection{Ultimate Deflection and Ductility}

Ductility factor $\mu$, is defined as the ultimate inelastic structural deflection, $\Delta_{\mathrm{u}}$, to the yield strength deflection, $\Delta_{\mathrm{y}}$. Since these slabs are greatly ductile and can reach ultimate inelastic deflection far more than any loading code allowable deflection, the ultimate inelastic deflection of slabs used for calculating ductility factor, corresponds to the strength at which a $20 \%$ loss from maximum strength, $\mathrm{P}_{\max }$, is observed. The measured values of the ultimate deflection are plotted in Fig. (10a). As can be seen, slabs types D and F which were retrofitted with NSM-HPFRCC strips have gained the highest increases in the ultimate deflection, 50.9\% and 37.6\%, respectively. Also, in comparison with that of control slab No.2, these two slabs are more successful, since they present $27.7 \%$ and $16.4 \%$ increases. As mentioned earlier slab type E failed at the same deflection as of control slab No.1, thus, it shows only $2.6 \%$ increase in the ultimate deflection. In consequence, the evaluated values of ductility show the positive effect of the NSM-HPFRCC strips in increasing ductility, even more than that of flexural reinforcement. Slab type E shows an increase of $20.9 \%$ in ductility while slabs type D and F present $59.2 \%$ and $100.4 \%$ increases, respectively. The unexpected higher increase in ductility in slab type F can be explained by viewing its load-deflection response curve, which seems to have two stages of strain hardening. The first stage, which is dominated by the action of precast strips, extends from reinforcement yielding to maximum strength, followed by a strain softening trend towards the deflection of $32 \mathrm{~mm}$. After the occurrence of extensive cracking in the precast strips, cracks extended to the tension face of slab, where in-situ NSM-HPFRCC strips were also positioned in the same level, thus, the second stage of strain hardening starts with a smoother trend ending at the ultimate strength $\left(80 \%\right.$ of $\left.\mathrm{P}_{\max }\right)$. In contrast to the previous stage, the strain hardening behaviour in this stage is mainly a result of the NSM-HPFRCC strips, which were positioned in a higher level inside the tension face, and produced a delayed strain hardening action. Similar to toughness, the lowest increase in ductility is for slab type E which encountered strip debonding. Fig. (10b) shows the values of ductility calculated based on the ultimate deflections of different slabs. Again, it is obvious that the proposed retrofit configurations are able to enhance ductility, even more than steel reinforcement in control slab No.2.

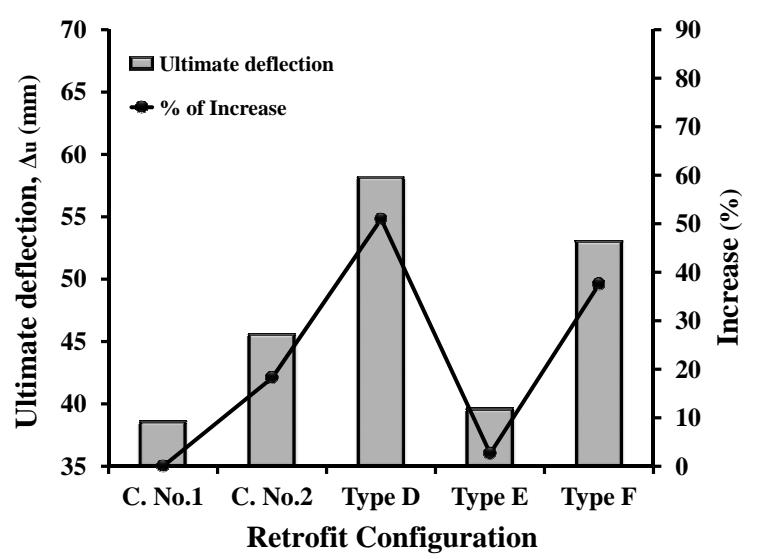

(a)

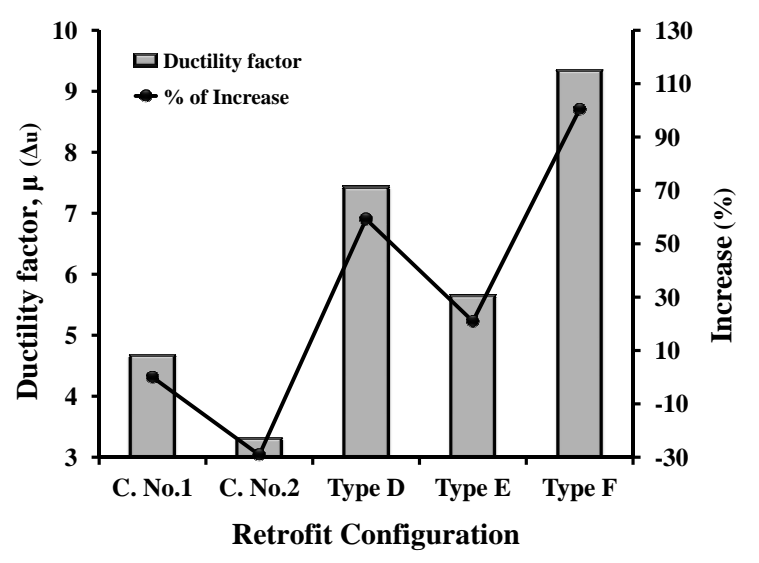

(b)

Fig. (10). Comparison of the values of (a) ultimate deflection and (b) ductility factor of control and retrofitted slabs. 


\subsection{Over-strength Factor and Maximum Strength}

The over-strength factor (R), which is a measure of the number of structural redundancies, strain hardening, deflection constraints, retrofit configuration and HPFRCC material properties, is determined from an inelastic response curve and considered as the ratio of maximum and yield strengths of retrofitted two-way RC slabs. Since the slabs were reinforced with the minimum steel reinforcement ratio, the effect of the number of structural redundancies is not very significant in the over-strength factor. This is obvious in control slab No.2, where it shows only $0.6 \%$ increase in overstrength factor. Only slab type E (19.8\% increase) shows higher value of over-strength factor in comparison with that of control slab No.1, (Fig. 11a). This is due to the higher difference between maximum and yielding strengths, and presents the action of strain hardening in improving the over-strength factor. Unlike ductility and initial stiffness, slab type $\mathrm{F}$ possesses the lowest value of over-strength factor among retrofitted slabs. Again, this shows the dominant action of precast strips in the first stage of strain hardening, where they were only positioned in one-way over the tension face of the two-way slab.

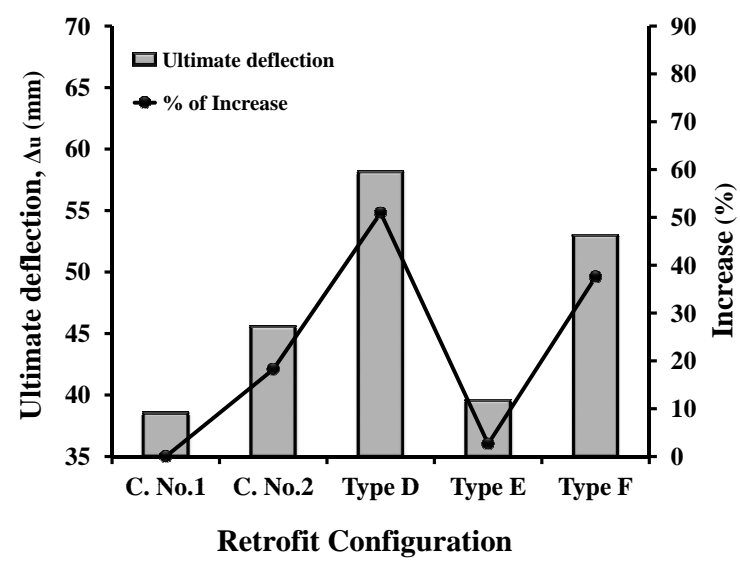

(a)

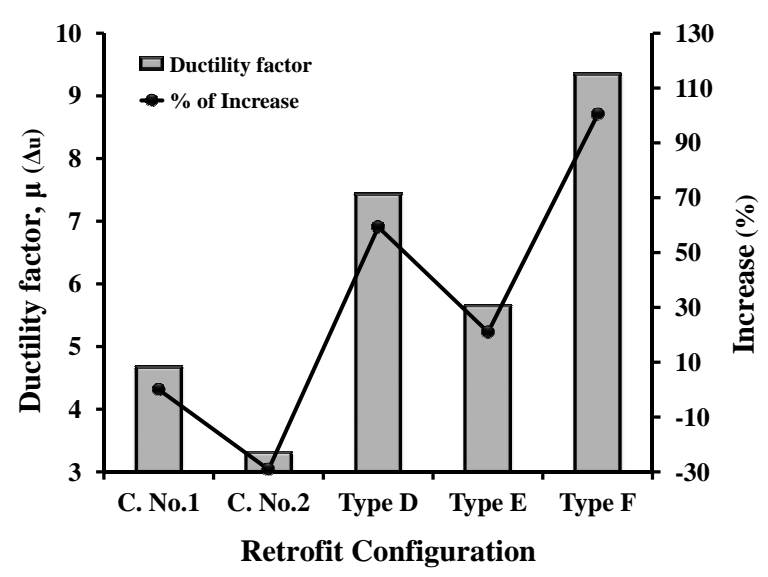

(b)

Fig. (11). Comparison of the values of (a) over-strength factor and (b) maximum strength of control and retrofitted slabs.

The last comparative parameter evaluated for slabs is the increase in maximum strength $\left(\mathrm{P}_{\max }\right)$, which reflects the effect of different types of HPFRCC strips in increasing the load bearing capacity. As expected, control slab No.2, having a reinforcement ratio two times that of other slabs, presented the highest increase in maximum strength (47\% increase) and among the retrofitted slabs, the highest increase is for slab type F, 25.3\%. Fig. (11b) shows the values of maximum strength for control and retrofitted slabs.

\section{SUMMARY AND CONCLUSION}

The proposed HPFRCC retrofit configurations presented their ability as an effective system for the strengthening of two-way RC slabs. The NSM-HPFRCC technique has the potential to considerably improve the flexural performance of retrofitted members in terms of toughness, initial stiffness, strength and ductility. Due to better anchorage of embedded NSM reinforcement, this "reinvented" technique showed to be significantly more efficient than EBR system not only by solving the problem of debonding, but by acting as repair material and improving the durability of existing structures. Some other results derived from the current study are listed below.

1. The full advantage of HPFRCC strips was achieved only when the bonding between the strips and slab was provided by either NSM technique or epoxy resin for in-situ and pre-cast strips, respectively.

2. While the two-way EBR strips cast over the tension face of slab type E encountered debonding, the retrofit configurations consisting of NSM strips in slabs type D and F showed no signs of debonding.

3. The retrofit configuration type F including both types of precast and NSM-HPFRCC strips showed a good combination of stiffness and ductility which is the dominant characteristic of each strip type, respectively. 
The results show the great influence of the proposed retrofit technique in enhancing the overall behaviour of the retrofitted slabs. Except slab type E, which encountered debonding, the two other retrofitted slabs were successful in recovering the flexural capacity of deficient slabs since they achieved higher values of toughness, initial stiffness and ductility compared with those of control slab No.2, conventional slab. Although, they presented lower efficiency in increasing the load-bearing capacity, still their responses due to the significant difference in the tensile strength of HPFRCC materials with that of steel reinforcement are deemed to be acceptable.

In conclusion, noting other benefits of HPFRCC materials such as low cost, availability, fire resistance and property matching with concrete, the proposed strengthening technique is considered to be a viable method for replacing the more expensive solutions. The findings of the current study due to the limitation in the number of tests are thought preliminary. Further research is needed to investigate other aspects such as HPFRCC material property, fibre type and volume fraction, different patterns, dimensions, or distance between grooves and strips.

\section{CONSENT FOR PUBLICATION}

Not applicable.

\section{CONFLICT OF INTEREST}

The authors declare no conflict of interest, financial or otherwise.

\section{ACKNOWLEDGEMENTS}

Declared none.

\section{REFERENCES}

[1] W. Radomski, Bridge Rehabilitation., Imperial College Press: London, 2002. [http://dx.doi.org/10.1142/p103]

[2] J.W. Zhang, J.G. Teng, Y.L. Wong, and Z.T. Lu, "Behavior of two-way RC slabs externally bonded with steel plate", J. Struct. Eng., vol. 127, no. 4, pp. 390-397, 2001.

[http://dx.doi.org/10.1061/(ASCE)0733-9445(2001)127:4(390)]

[3] U. Ebead, and H. Marzouk, "Strengthening of Two-Way Slabs Using Steel Plates", ACI Struct. J., vol. 99, no. 1, pp. 23-31, 2002.

[4] O. Limam, G. Foret, and A. Ehrlacher, "Two-way RC slab strengthened with CFRP strips: experimental study and a limit analysis approach", Compos. Struct., vol. 60, pp. 467-471, 2003. [http://dx.doi.org/10.1016/S0263-8223(03)00011-4]

[5] K. Qian , and B. Li, "Strengthening and Retrofitting of RC Flat Slabs to Mitigate Progressive Collapse by Externally Bonded CFRP Laminates", J. Compos. Constr., vol. 17, pp. 554-565, 2013. [http://dx.doi.org/10.1061/(ASCE)CC.1943-5614.0000352]

[6] C.G. Papanicolaou, T.C. Triantafillou, I. Papantoniou, and C. Balioukos, "Strengthening of two-way slabs with textile-reinforced mortars (TRM)", In: Proc. 11th Intern. fib Symp., London, 2009.

[7] L.N. Koutas, and D.A. Bournas, "Flexural Strengthening of Two-Way RC Slabs with Textile-Reinforced Mortar: Experimental Investigation and Design Equations", J. Compos. Constr., vol. 21, no. 1, 2017.

[http://dx.doi.org/10.1061/(ASCE)CC.1943-5614.0000713]

[8] Z. Kexin, and S. Quansheng, "Strengthening of a Reinforced Concrete Bridge with Polyurethane-cement Composite (PUC)", Open Civ. Eng. J., vol. 10, pp. 768-781, 2016. [http://dx.doi.org/10.2174/1874149501610010768]

[9] R. Jones, R.N. Swamy, and A. Charif, "Plate separation and anchorage of reinforced concrete beams strengthened by epoxy-bonded steel plates", ASCE J. Str. Eng, vol. 66, no. 5, pp. 85-94, 1998.

[10] M. Hussain, A. Sharif, I.A. Basenbul, M.H. Baluch, and G.J. Al-Sulaimani, "Flexural behavior of pre-cracked reinforced concrete beams strengthened externally by steel plates", ACI Struct. J., vol. 92, no. 1, pp. 14-22, 1995.

[11] U. Ebead, and H. Marzouk, "Fiber-reinforced polymer strengthening of two-way slabs", ACI Struct. J., vol. 101, no. 5, pp. 650-659, 2004.

[12] A.E. Naaman, and H.W. Reinhardt, Characterization of high performance fiber reinforced cement composites, HPFRCC-2, 1996, pp. 1-24.

[13] V.C. Li, and H.C. Wu, "Conditions for pseudo strain-hardening in fiber reinforced brittle matrix composites", J. Applied Mechanics Review, vol. 45 , no. 8 , pp. $390-398,1992$.

[http://dx.doi.org/10.1115/1.3119767]

[14] V.C. Li, "From micromechanics to structural engineering - the design of cementitious composites for civil engineering applications", JSCE J. Str. Mech. Earthquake Eng, vol. 10, no. 2, pp. 37-48, 1993. 
[15] F.J. Alaee, "Retrofitting of Concrete Structures using High Performance Fiber Reinforced Cementitious Composite (HPFRCC)", PhD thesis," Cardiff University, Cardiff, 2002.

[16] H.D. Yun, K. Rokugo, T. Izuka, and S.C. Limcrack, "Crack-damage mitigation of RC one-way slabs with a strain-hardening cement-based composite layer", Mag. Concr. Res., vol. 63, no. 7, pp. 493-509, 2011. [http://dx.doi.org/10.1680/macr.2011.63.7.493]

[17] M.G. Naghibdehi, M.K. Sharbatdar, M. Mastali, and M.G. Naghibdehi, "Flexural performance of functionally graded RC cross-section with steel and PP fibers", Mag. Concr. Res., vol. 66, no. 5, pp. 219-233, 2014. [http://dx.doi.org/10.1680/macr.13.00248]

[18] N. Banthia, and N. Nandakumar, "Crack growth resistance of hybrid fiber reinforced cement composites", J. Cem. Concr. Compos., vol. 25, no. 1, pp. 3-9, 2003.

[http://dx.doi.org/10.1016/S0958-9465(01)00043-9]

[19] W. Meng, M. Valipour, and K.H. Khayat, "Optimization and performance of cost-effective ultra-high performance concrete", Mater. Struct., vol. 50 , no. 1, p. $29,2017$. [http://dx.doi.org/10.1617/s11527-016-0896-3]

[20] W. Meng, and K.H. Khayat, "Improving flexural behavior of ultra-high performance concrete by rheology control", Composites B: Eng., vol. 117, pp. 26-34, 2017. [http://dx.doi.org/10.1016/j.compositesb.2017.02.019]

[21] V.C. Li, S. Wang, and C. Wu, "Tensile strain-hardening behavior of polyvinyl alcohol-engineered cementitious composite (PVA-ECC)", ACI Mater. J., vol. 98, no. 6, pp. 483-492, 2001.

[22] A. Hemmati, A. Kheyroddin, and M.K. Sharbatdar, "Plastic Hinge Rotation Capacity of Reinforced HPFRCC Beams", J. Struct. Eng., vol. 141 , no. 2, 2013. [http://dx.doi.org/10.1061/(ASCE)ST.1943-541X.0000858]

[23] A. Hemmati, A. Kheyroddin, and M.K. Sharbatdar, "Increasing the flexural capacity of RC beams using partially HPFRCC layers", Comput. Concr., vol. 16, no. 4, pp. 545-568, 2015.

[http://dx.doi.org/10.12989/cac.2015.16.4.545]

[24] V.J. Ferrari, J.B. Hanai, and R.A. Souza, "Flexural strengthening of reinforcement concrete beams using high performance fiber reinforcement cement-based composite (HPFRCC) and carbon fiber reinforced polymers (CFRP)", Constr. Build. Mater., vol. 48, pp. 485-498, 2013.

[http://dx.doi.org/10.1016/j.conbuildmat.2013.07.026]

[25] C.A. Jeyasehar, and R. Balamuralikrishnan, "Strengthening of structures by HPFRCC laminates", Asian J. Civil Eng., vol. 13, no. 1, pp. 29-42, 2012.

[26] M.J. Radik, E. Erdogmus, and T. Schafer, "Strengthening Two-Way Reinforced Concrete Floor Slabs Using Polypropylene Fiber Reinforcement", J. Mater. Civ. Eng., vol. 23, pp. 562-571, 2011. [http://dx.doi.org/10.1061/(ASCE)MT.1943-5533.0000206]

[27] X. Li, J. Wang, Y. Bao, and G. Chen, "Cyclic behavior of damaged reinforced concrete columns repaired with environment-friendly fiberreinforced cementitious composites", Eng. Struct., vol. 136, pp. 26-35, 2017. [http://dx.doi.org/10.1016/j.engstruct.2017.01.015]

[28] H.M. Afefy, and M. Hussein, "Structural performance of RC slabs provided by pre-cast ECC strips in tension cover zone", Constr. Build. Mater., vol. 65, pp. 103-113, 2014.

[http://dx.doi.org/10.1016/j.conbuildmat.2014.04.096]

[29] W. Meng, and K.H. Khayat, "Experimental and numerical studies on flexural behavior of ultra-high-performance concrete panels reinforced with embedded glass fiber-reinforced polymer grids", Transp. Res. Rec., no. 2592, pp. 38-44, 2016. [http://dx.doi.org/10.3141/2592-05]

[30] H. Marzouk, and A. Hussein, "Experimental Investigation on the Behavior of High-Strength Concrete Slabs", ACI Struct. J., vol. 88, no. 6, pp. 701-713, 1991.

[31] ACI committee 318, Building code requirements for structural concrete, Farmington Hills (MI), American Concrete Institute, ACI., pp. 318-99, 1999.

[32] S.O. Asplund, "Strengthening bridge slabs with grouted reinforcement", ACI J., vol. 20, no. 6, pp. 397-406, 1949.

[33] K. Tan, G. Tumialan, and A. Nanni, "Evaluation of CFRP systems for the strengthening of RC slabs", In: Rep. CIES 02-38., Center for Infrastructure Engineering Studies, Univ. of Missouri-Rolla: Rolla, Mo, 2002.

[34] T. Hassan, and S. Rizkalla, "Investigation of bond in concrete structures strengthened with near surface mounted carbon fiber reinforced polymer strips", J. Compos. Constr., vol. 7, no. 3, pp. 248-257, 2003. [http://dx.doi.org/10.1061/(ASCE)1090-0268(2003)7:3(248)]

[35] G.M. Dalfré, and J.A. Barros, "NSM technique to increase the load carrying capacity of continuous RC slabs", Eng. Struct. J., vol. 56, pp. 137-153, 2013. [http://dx.doi.org/10.1016/j.engstruct.2013.04.021] 
[36] M.R. Mostakhdemin Hosseini, S.J. Dias, and J.A. Barros, "Effectiveness of prestressed NSM CFRP laminates for the flexural strengthening of RC slabs", Compos. Struct. J., vol. 111, pp. 249-258, 2014.

[http://dx.doi.org/10.1016/j.compstruct.2013.12.018]

[37] M. Breveglieri, J.A. Barros, G.M. Dalfré, and A. Aprile, "A parametric study on the effectiveness of the NSM technique for the flexural strengthening of continuous RC slabs", Compos. Part B. Eng., vol. 43, no. 4, pp. 1970-1987, 2012.

[http://dx.doi.org/10.1016/j.compositesb.2012.02.008]

\section{(C) 2017 Abbaszadeh et al.}

This is an open access article distributed under the terms of the Creative Commons Attribution 4.0 International Public License (CC-BY 4.0), a copy of which is available at: https://creativecommons.org/licenses/by/4.0/legalcode. This license permits unrestricted use, distribution, and reproduction in any medium, provided the original author and source are credited. 